\title{
Fate and source distribution of organic constituents in a river-dominated tropical estuary
}

\author{
P M Salas, C H Sujatha* and C S Ratheesh Kumar \\ Department of Chemical Oceanography, School of Marine Sciences, Cochin University of Science and Technology, \\ Kochi 682 022, India. \\ *Corresponding author. e-mail: drchsujatha@yahoo.co.in
}

\begin{abstract}
We investigated spatial and temporal changes in the quality of sedimentary organic matter and trophic status of the Cochin estuarine system, southwest coast of India. Sediment samples were collected in five sampling campaigns from January 2009 to April 2010. TOC/N ratio implied mixed input of autochthonous as well as remarkable allochthonous terrestrial higher plant debris into the sedimentary system. More depleted $\delta^{13} \mathrm{C}$ values at riverine and industrial zone suggested a major contribution of terrestrial higher plant debris to sedimentary organic matter. Trophic status of the estuary changed seasonally to eutrophic via oligotrophic and mesotrophic conditions during the period January 2009 to April 2010. The protein to carbohydrate ratio was lower $(<1)$, indicating heterotrophic nature and the higher lipid to carbohydrate ratio $(>1)$ denoted preservation of lipid compounds in the sediments. Correlation analyses provide evidence of the association of chlorophyll pigments with carbohydrates and account for the highly productive nature of the estuary and algal contributions to organic matter. Canonical correspondence analysis clearly illustrated prominence of phaeopigments in fishing zone, lipids in sewage/tourism influenced zone, carbohydrates in riverine zone and proteins in industrial zone. It also indicated the influence of sedimentary texture, $\mathrm{pH}$ and organic carbon to the distribution of biochemical constituents.
\end{abstract}

\section{Introduction}

Source characterization of organic matter (OM) within the estuarine sediments is of utmost importance in understanding the autochthonous and allochthonous input as well as to assess global biogeochemical cycles (Yamamuro 2000; Goni et al. 2003). In situ biological production and accumulation of marine and terrestrial particles have been recognized as the significant sources of OM implies to the estuarine sediments (Mayer et al. 1988; Cifuentes 1991). Urban sewage inputs strongly influence the quantity and quality of incoming materials in the sediments and therefore the nature of organic materials depend on complex physicochemical processes occurring in overlying water layers and in the sediments (Cotano and Villate 2006). Bulk geochemical parameters are available for the evaluation of OM sources and its fate within marine sediments, including biochemical composition, elemental and stable isotope ratios. Biochemical composition serves not only as a valid methodology to determine the origin of organic matter (Colombo et al. 1996), but also as a useful tool to evaluate the nutritional quality of organic materials as available food for benthic consumer organisms (Dell'Anno et al. 2000; Rossi et al. 2001; Rossi and Lardicci 2002; Cividanes et al. 2002; Joseph et al. 2008). Composition of $\mathrm{OM}$ in sediments has been recognized as the major

Keywords. Sediments; quality; organic matter; biochemical components; trophic status. 
factor affecting metabolism, distribution and dynamics of benthic organisms (Grant and Hargrave 1987; Graf 1989; Duineveld et al. 1997) and has been widely employed to evaluate the trophic state of both marine and estuarine ecosystems (Cloern 2001; Renjith et al. 2012; Akhil et al. 2013). The portion of sedimentary OM which are more readily available to benthic consumers (labile fraction), has usually been assessed by estimation of the main biochemical classes of organic compounds (Fichez 1991; Danovaro et al. 1993; Fabiano et al. 1995; Dell'Anno et al. 2002).

Cochin estuary is a highly productive ecosystem, and its complex nature is attributed to permanent connection with the Arabian Sea and the input of significant quantities of $\mathrm{OM}$ and nutrients (Srinivas 2000). Large quantities of sewages and other untreated and partially-treated pollutants have been discharged into the estuary, which causes significant toxic impact on the aquatic environment (Balachandran et al. 2005, 2008). Even though the estuary has been found to be a site of positive net ecosystem production (Qasim 2003), a seasonal shift in net pelagic production to heterotrophic conditions owing to terrestrial input of OM has also been reported (Thottathil et al. 2008). Even though, information regarding the organic geochemical aspects of sediments in the Cochin estuarine system is available (Aneeshkumar and Sujatha 2012; Gireeshkumar et al. 2012; Renjith et al. 2012; Akhil et al. 2013), a long term monitoring and detailed description of the sedimentary variables is yet to be attempted. All these investigations have repeatedly demonstrated the role of industrialisation, urbanisation and other anthropogenic interventions, creating alterations in the biogeochemical aspects and ecological functioning of this sensitive ecosystem. Repeated regular assessment coupled with seasonal changes is a prerequisite for evaluating the current health status of a deteriorating and vulnerable ecosystem. All these factors prompted us to carry out a long term investigation to identify the nature and origin of organic matter and its distribution pattern in the estuary. The study aims at:

(i) a comparative evaluation of spatio-temporal variability in biochemical components and the processes governing their distribution,

(ii) to assess the quantity and quality of sedimentary organic matter, and

(iii) identify the distribution pattern and source characterization of sedimentary organic matter in the Cochin estuarine system using bulk parameters.

The information furnished in the present investigations will be helpful to future researchers as reference data for formulating remedial environmental conservation strategies.

\section{Data and methods}

The Cochin estuarine system - CES (latitude: $9^{\circ} 40^{\prime}$ and $10^{\circ} 12^{\prime} \mathrm{N}$ and longitude: $76^{\circ} 10^{\prime}$ and $\left.76^{\circ} 30^{\prime} \mathrm{E}\right)$ forms a complex network of shallow brackish water $\left(250 \mathrm{~km}^{2}\right)$ running parallel to the coast, and has been designated as a 'Ramsar site' (No. 1214, figure 1). This tropical aquatic system is under the profound influence of the southwest monsoon (Jayaprakash 2002), accordingly three seasonal conditions prevailing, viz., monsoon (JuneSeptember), post-monsoon (October-January) and pre-monsoon (February-May). Six rivers (namely: Periyar, Muvattupuzha, Pamba, Manimala, Meenachil and Achencovil) discharge about $20,000 \times 10^{6} \mathrm{~m}^{3}$ of fresh water into the estuary annually (Srinivas 2000). Hydrobiological studies (Menon et al. 2000) reflected high flushing taking place in the water body during the monsoon. The variation in the river discharge and heavy rain fall induces a salinity gradient, which is responsible for the diverse biotopes of plankton communities in the estuary (Dayala et al. 2014). The northwestern part frequently develops flow restrictions due to converging tides entering from two adjacent inlets, whereas the southern arm experiences tidal amplification (Balachandran et al. 2008). This well-known biodiverse wetland is under the threat of severe ecological degradation due to massive reclamation (Gopalan et al. 1983) and increased industrialisation and urbanisation (Menon et al. 2000; Qasim 2003). In this context, the surface sediment samples were collected from fifteen selected sites (figure 1). Karippadam (S1), Murinjapuzha-Enadhi (S2), MurinjapuzhaBhramamangalam (S3) and Murinjapuzha (S4) were categorised as riverine zone, while, Perumbalam (S5), Aroor (S6) and Thevara (S7) were referred as fishing zone. The central part of the study area includes: Marine Sciences Jetty (S8), Bolgatty (S9) and Mulavukad (S10), were classified as sewage/tourism influenced zone. While the stations, Chennoor (S11), Cheranellur (S12), Eloor (S13), Edayar (S14) and Kalamassery (S15) together constituted the industrial zone.

Surface sediment samples $(5 \mathrm{~cm})$ were collected from the selected stations along the Cochin estuary by a van Veen grab $\left(0.042 \mathrm{~m}^{2}\right)$ in five sampling campaigns, viz., January 2009 (post-monsoon; POM09), April 2009 (pre-monsoon; PRM09), August 2009 (monsoon; MON09), January 2010 (post-monsoon; POM10) and April 2010 (premonsoon; PRM10). The sediment $\mathrm{pH}$ was determined in situ using a portable $\mathrm{pH}$ meter (Eutech, 

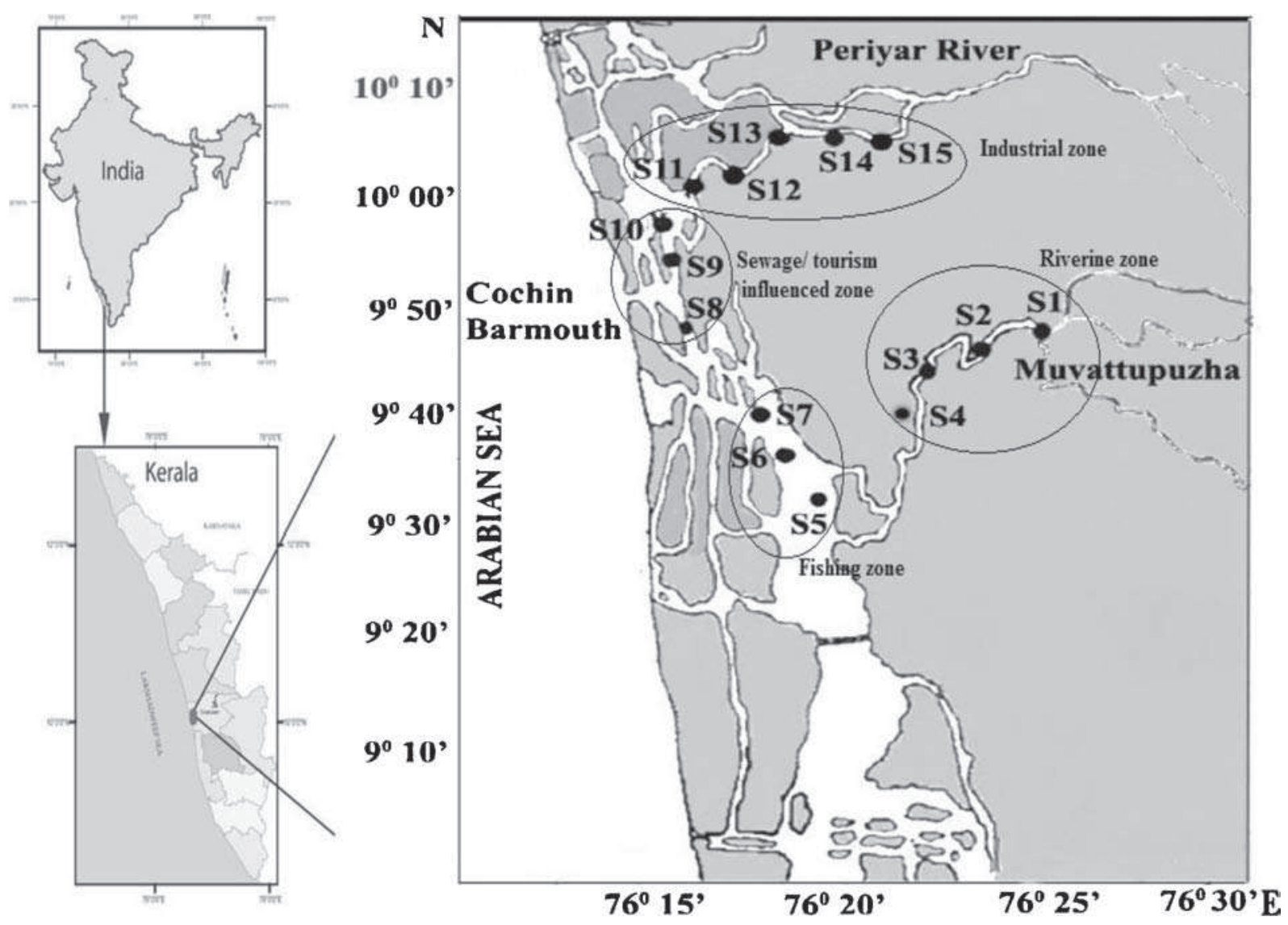

Figure 1. Location map of the study area.

pH Tester 10). Redox potential of the wet sediments were measured by portable Eh meter (Eutech, ORP Testr 10), calibrated with Zobell solution. Texture of the sediments was determined by pipette analysis after removing the inorganic carbonates using $10 \% \mathrm{HCl}$ and the organic matter using $\mathrm{H}_{2} \mathrm{O}_{2}$ (Folk 1974). Sediments were freezedried, homogenised using agate mortar and pestle and were used for the estimation of geochemical variables. Total nitrogen $(\mathrm{N})$ and total sulphur (S) were determined using CHNS analyzer (Vario EL III). Total organic carbon (TOC) was estimated by TOC analyzer (VARIO TOC SELECTElementar), after removing inorganic carbon using $2 \mathrm{M} \mathrm{HCl}$.

Analysis of protein (PRT) was carried out by spectrophotometric method (Lowry et al. 1951; Rice 1982) using bovine albumin as standard. Total carbohydrates (CHO) were estimated according to Dubois et al. (1956) employing glucose as standard. Total lipids (LPD) were extracted according to Bligh and Dyer (1959) and were estimated according to Barnes and Blackstock (1973) utilising cholesterol as calibration standard. Tannin and lignin (TL) in sediments were estimated spectrophotometrically by the sodium tungstatephosphomolybdic acid method (Nair et al. 1989;
APHA 1995). Chlorophyll and phaeopigments (Phe) estimations were carried out according to standard procedures (Lorenzen and Jeffrey 1980; APHA 1995). Pigments were extracted with $90 \%$ acetone $\left(24 \mathrm{hr}\right.$ in the dark at $\left.4^{\circ} \mathrm{C}\right)$. After centrifugation, the supernatant was used to determine chlorophyll pigments ( $\operatorname{chl}-a$, chl- $b$ and $\operatorname{chl}-c$ ) and was acidified with $0.1 \mathrm{~N} \mathrm{HCl}$ to estimate the concentration of phaeopigments. Concentrations of protein, carbohydrate and lipid were converted to carbon equivalents by using the following conversion factors: $0.49,0.40$ and $0.75 \mathrm{~g}$ of $\mathrm{C} / \mathrm{g}$, respectively (Fabiano and Danovaro 1994). The sum of protein, carbohydrate and lipid carbon is referred as biopolymeric carbon (BPC) (Fichez 1991; Fabiano et al. 1995). The algal contribution to BPC was calculated as the percentage of chl- $a$ to BPC concentrations, after converting chl- $a$ concentration into carbon equivalents, by applying a mean value of 40 (Pusceddu et al. 2009). Stable carbon isotope analysis of total organic matter was carried out using Flash EA interfaced with Isotope Ratio Mass Spectrometer (FINNIGAN DELTA PLUS XP, Thermo Electron Corporation). Stable carbon isotope abundances were presented as $\delta^{13} \mathrm{C}$ values and were expressed relative to the Pee Dee Belemnite (PDB) standard. Measurement/estimation of 
all the variables were carried out in triplicate and the average value/concentration was reported.

Analysis of variance (ANOVA - two-way without replication) was employed to evaluate the spatial and temporal distributions of the parameters in the study region. Pearson correlation (derived using software SPSS 13) and canonical correspondence analysis (XLSTAT version 2014.6.03) were employed to identify the source of organic matter as well as the process governing the distribution of various geochemical variables in sediments.

\section{Results and discussion}

The grain size has immense influence on the distribution of various sedimentary parameters in the aquatic environments (Prasad and Ramanathan 2008; Wen et al. 2008; Renjith et al. 2011). Texture analysis showed a progressive increase in fine fractions from riverine zone to the sewage/tourism influenced zone (figure 2). Increased river run-off associated with high precipitation during monsoon (Menon et al. 2000) results in higher sand content, more prominently at the industrial zone (S13, MON09). The textural composition of the sediment displayed distinct spatial as well as seasonal variations $(\mathrm{p}<0.01)$. Considerable alterations in the texture was observed in the sediments of fishing (S5-S7), sewage/tourism influenced (S8-S10), riverine zone (S1-S4) and industrial zone (S11S15). Sediments from a majority of stations exhibited significant fluctuations in textural characteristics indicating the discharge dependency in the study area. Fine sediments get entrained during the river run-off, leaving behind the coarser sediments in the river-dominated locations of the study region. Sorting processes like scouring by tides, result in re-suspension and flushing out of sediments (Muraleedharan Nair and Ramachandran 2002). Furthermore, the complex current pattern prevailing in the estuarine area also contributes to the textural inhomogeneity in sediments (Rasheed 1997).

$\mathrm{pH}$ of the sediment was mainly controlled by the river run-off as well as ingression of sea water from the Arabian Sea and fluctuated between 6.65 (S12; PRM10) and 8.3 (S8; PRM09). The observed range for redox potential was noted to be from -345 (S9; PRM09) to $21 \mathrm{mV}$ (S2; PRM10), providing clues for degradation of organic matter in sediments. Qualitative evaluation of the redox status of the sedimentary environment was assessed by total organic carbon to sulphur ratios (Raiswell et al. 1987). Typically TOC/S ratios $>5$ has been categorized as oxic sediment with oxygenated bottom water, $\mathrm{TOC} / \mathrm{S}=1.5-5$ indicates sediments deposited under periodic anoxia and
TOC $/ \mathrm{S}<1.5$ reflect anoxic sediments with anoxic water (Raiswell et al. 1987). The estimated TOC/S values (range: $0.30-9.52$ ) pointed out that most of the stations were under the influence of periodic anoxia, where sediments undergo sulphate reduction below an oxygenated water column (Niffy Benny 2009; Renjith et al. 2012; Akhil et al. 2013).

Higher concentration of TOC (range: 0.16$6.39 \%$ ) recorded in fine-grained sediments, seems to display remarkable spatial variation $(\mathrm{p}<0.01)$. The distribution pattern of TOC with texture is depicted in figure 2. During the investigation, TOC levels were high in the riverine (S1, S2, S3) and industrial zones (S12, S14, S15), on account of the transport of allochthonous material via terrestrial run-off (Martin et al. 2010; Gireeshkumar et al. 2012; Renjith et al. 2012). Surficial sediments of the CES recorded a moderate level of TOC comparable to previous studies (Balachandran et al. 2005; Joseph et al. 2008; Martin et al. 2010; Deepulal et al. 2012; Gireeshkumar et al. 2012; Renjith et al. 2012; Akhil et al. 2013). Organic matter constitutes an integral part of aquatic sediments and its distribution pattern in the study region was noted to be governed by the in situ primary production, supply rate of terrestrial materials, deposition rate and texture of the sediments. Textural control over TOC was indicated by the correlation of TOC with sand, silt and clay sediments. TOC exhibited a significant positive correlation with both silt $(r=0.32)$ and clay $(r=0.25)$ and an inverse relationship with that of sand $(r=-0.33)$ in the estuarine sediments (table 2). Positive relationship of TOC with clay and silt (figure 2) indicated its size-dependent scavenging (Muraleedharan Nair and Ramachandran 2002). Coatings of organic matter onto clay minerals tend to affect size distribution and settling rates of sediments (Cotano and Villate 2006; Ramaswamy et al. 2008).

Seasonal variation in the estimated biochemical components in sediments, followed the trend: $\mathrm{LPD}>\mathrm{CHO}>\mathrm{PRT}-\mathrm{POM} 09, \mathrm{CHO}>\mathrm{PRT}>\mathrm{LPD}-$ PRM09, CHO > PRT > LPD-MON09, PRT $>$ CHO > LPD-PRM10, PRT > CHO > LPD-POM10. Total carbohydrate in the sediments (table 1 ) varied from 434.19 to $12839 \mathrm{mg} / \mathrm{kg}$ with significant spatial variations $(p<0.01)$. The increased contents of $\mathrm{CHO}$ (figure 3) was recorded at riverine (S1) and industrial zone (S12, S14, S15) implying greater contribution of vascular plant debris to sedimentary OM (Cowie and Hedges 1984). Furthermore, the predominant concentration of $\mathrm{CHO}$ over PRT and LPD during PRM09 and MON09 (figure 3) indicated the input of allochthonous terrestrially derived $\mathrm{OM}$ and the detrital-heterotrophic nature of CES (Danovaro 1996; Renjith et al. 2012). The observed levels of $\mathrm{CHO}$ were in good agreement 

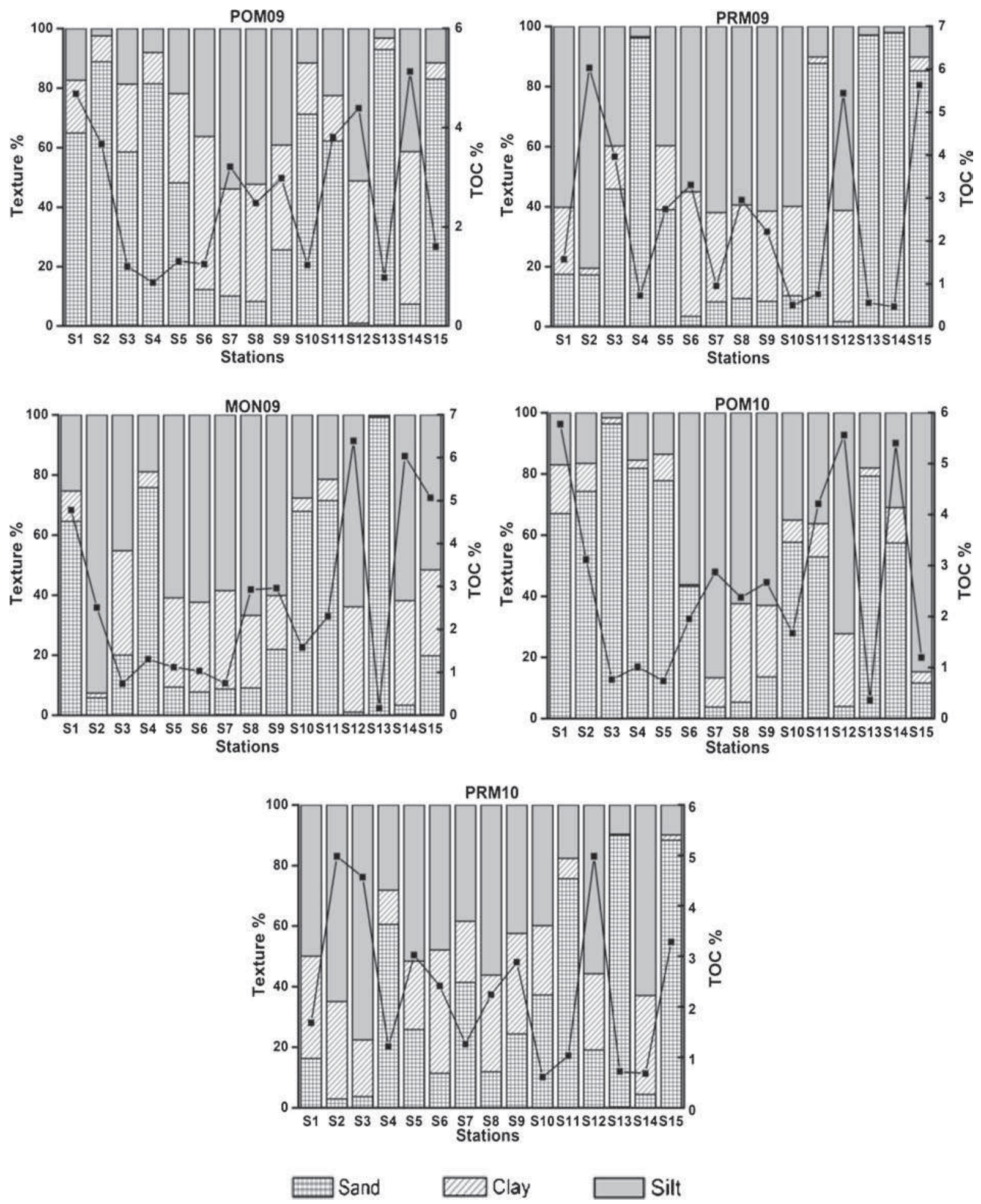

Figure 2. Seasonal and spatial variations of sediment texture and TOC in the study area.

with other estuaries (table 4) and the previous studies of this wetland ecosystem (Joseph et al. 2008; Renjith et al. 2012; Akhil et al. 2013).

Lipids are produced by living organisms and constitute an important fraction of dissolved and particulate $\mathrm{OM}$ in aquatic environments (Borsheim et al. 1999; Burdige et al. 2000). It constitutes a major portion of the labile OM and has implications on meiofauna abundance and biomass (Cartes et al. 2002; Gremare et al. 2002). Elevated levels of total lipids (range: $115.29-8450 \mathrm{mg} / \mathrm{kg}$ ) reported in the present investigation reflected the productive nature and effective biological activity (Gremare et al. 1997; Akhil et al. 2013). A surplus of 
Table 1. The minimum, maximum, average and spatio-temporal variation ( $p$ value - ANOVA) of general sedimentary characteristics and various biochemical components in the study area.

\begin{tabular}{|c|c|c|c|c|c|}
\hline \multirow[b]{2}{*}{ Parameters } & \multirow[b]{2}{*}{ Minimum } & \multirow[b]{2}{*}{ Maximum } & \multirow[b]{2}{*}{ Average } & \multicolumn{2}{|c|}{ ANOVA (p value) } \\
\hline & & & & Spatial & Seasonal \\
\hline Sand $(\%)$ & 0.9 & 99.14 & $40.87 \pm 33.72$ & $<0.01$ & 0.25 \\
\hline Clay (\%) & 0.09 & 51.42 & $19.41 \pm 14.20$ & $<0.01$ & $<0.01$ \\
\hline Silt $(\%)$ & 0.24 & 86.6 & $39.72 \pm 24.33$ & $<0.01$ & 0.03 \\
\hline TOC $(\%)$ & 0.16 & 6.39 & $2.58 \pm 1.79$ & $<0.01$ & 0.98 \\
\hline Total nitrogen (N\%) & 0.02 & 1.07 & $0.18 \pm 0.25$ & 0.08 & $<0.01$ \\
\hline Total sulphur (S\%) & 0.16 & 3.10 & $1.18 \pm 0.74$ & $<0.01$ & 0.64 \\
\hline Total protein $(\mathrm{mg} / \mathrm{kg})$ & 110.67 & 19420 & $2338 \pm 3627$ & 0.039 & 0.65 \\
\hline Total carbohydrate $(\mathrm{mg} / \mathrm{kg})$ & 434.19 & 12839 & $2947 \pm 2547$ & $<0.01$ & 0.53 \\
\hline Total lipid $(\mathrm{mg} / \mathrm{kg})$ & 115.29 & 8450 & $2303 \pm 1860$ & $<0.01$ & 0.01 \\
\hline Chlorophyll $a(\mu \mathrm{g} / \mathrm{kg})$ & 0.36 & 18.49 & $7.55 \pm 4.91$ & $<0.01$ & 0.29 \\
\hline Chlorophyll $b(\mu \mathrm{g} / \mathrm{kg})$ & 0.24 & 16.00 & $3.83 \pm 2.57$ & $<0.01$ & 0.17 \\
\hline Chlorophyll $c(\mu \mathrm{g} / \mathrm{kg})$ & 0.23 & 26.20 & $4.48 \pm 3.46$ & 0.02 & 0.17 \\
\hline Phaeophytin $(\mu \mathrm{g} / \mathrm{kg})$ & 1.33 & 28.98 & $13.07 \pm 8.24$ & $<0.01$ & 0.22 \\
\hline $\mathrm{TL}(\mathrm{mg} / \mathrm{kg})$ & 7.18 & 6706 & $1379 \pm 1415$ & $<0.01$ & $<0.01$ \\
\hline$\delta^{13} \mathrm{C}(\%)$ & -32.34 & -25.39 & $-27.91 \pm 1.82$ & $<0.01$ & $<0.01$ \\
\hline
\end{tabular}

allochthonous OM input to the Cochin estuarine system has already been reported (Balachandran et al. 2003; Babu et al. 2006; Thottathil et al. 2008; Martin et al. 2010) and the observed data provided evidence for terrestrial input. Comparatively higher concentrations of dissolved and particulate organic carbon generated from sewage is delivered through various canals linked to Cochin estuary (Martin et al. 2010). The general distribution pattern of lipids (comparable with other studies - table 4), revealed a higher concentration at the industrial zone (figure 3 ) indicating terrestrial run-off coupled with industrial input. The riverine and fishing zones receive organic waste materials from aquaculture, agricultural activities as well as coconut retting yards (Thomson 2002; Babu et al. 2006; Martin et al. 2010), which alters the composition of sedimentary organic matter.

It is a well-known fact that proteins constitute a significant portion of labile sedimentary organics, originating from autochthonous as well as allochthonous inputs. Compared to the other studies (table 4), wide fluctuations in PRT content (range: $110.67-19420 \mathrm{mg} / \mathrm{kg}$ ) were noticed in the present investigation (figure 3 ); with strong spatial variability $(\mathrm{p}<0.01)$. The maximum concentration of PRT was noted at industrial zone (S14). Fish processing units situated on the banks of CES release enormous quantities of waste materials into the estuary contributing OM enriched with protein, which is ultimately adsorbed/settled in the sediment phase (Vasudevan 2000; Balasubramanian et al. 2012). Figure 3 clearly illustrates that riverine and industrial zones were characterized by higher levels of PRT indicating anthropogenic interventions altering the distribution pattern.
Lipid content and lipid to carbohydrate ratio (LPD/CHO) have been used as a powerful index to describe the food quality of the OM in the sediments (Fabiano and Pusceddu 1998; Gremare et al. 2002). It has been established that the lipid concentration in sediments is a good descriptor of the benthic trophic status (Danovaro et al. 1999, 2000; Dell'Anno et al. 2002) and the observed values were comparable with the previous reports (Joseph et al. 2008; Renjith et al. 2012). The LPD/CHO ratio ranged from 0.08 to 3.85 (figure $4 \mathrm{a}$ ) with a maximum value at the riverine zone (S2) during POM09, which implied high nutritional value as well as the freshness of OM in the sedimentary environment. Significantly lower ratios observed during the monsoon season $(p<0.01)$ provided a clear evidence of lower productivity and higher allochthonous organic input associated with land runoff (Jacob et al. 2008, 2009).

$\mathrm{PRT} / \mathrm{CHO}$ has been used as an index to determine the origin of $\mathrm{OM}$ in sediments and to distinguish between fresh and aged OM (Danovaro et al. 1993; Cividanes et al. 2002). Marked variation in PRT/CHO was seen and varied, from 0.04 (S6; PRM10) to 2.66 (S2; POM09), which coincide with the previous observations (Joseph et al. 2008). Figure 4(b) illustrates, lower PRT/CHO ratio $(<1)$ at most of the stations which could be due to accumulation of higher plant debris enriched with carbohydrates (Danovaro 1996). But the enhanced $\mathrm{PRT} / \mathrm{CHO}$ ratio $(>1)$ recorded in a few stations (figure 4b) established freshly deposited detritus (Danovaro et al. 1993).

Estimated chlorophyll pigments exhibited a spatial variation $(\mathrm{p}<0.01)$ and were in the range: chl- $a$ : $0.36-18.49 \mu \mathrm{g} / \mathrm{kg}, \quad c h l-b: \quad 0.24-16 \mu \mathrm{g} / \mathrm{kg}$, 

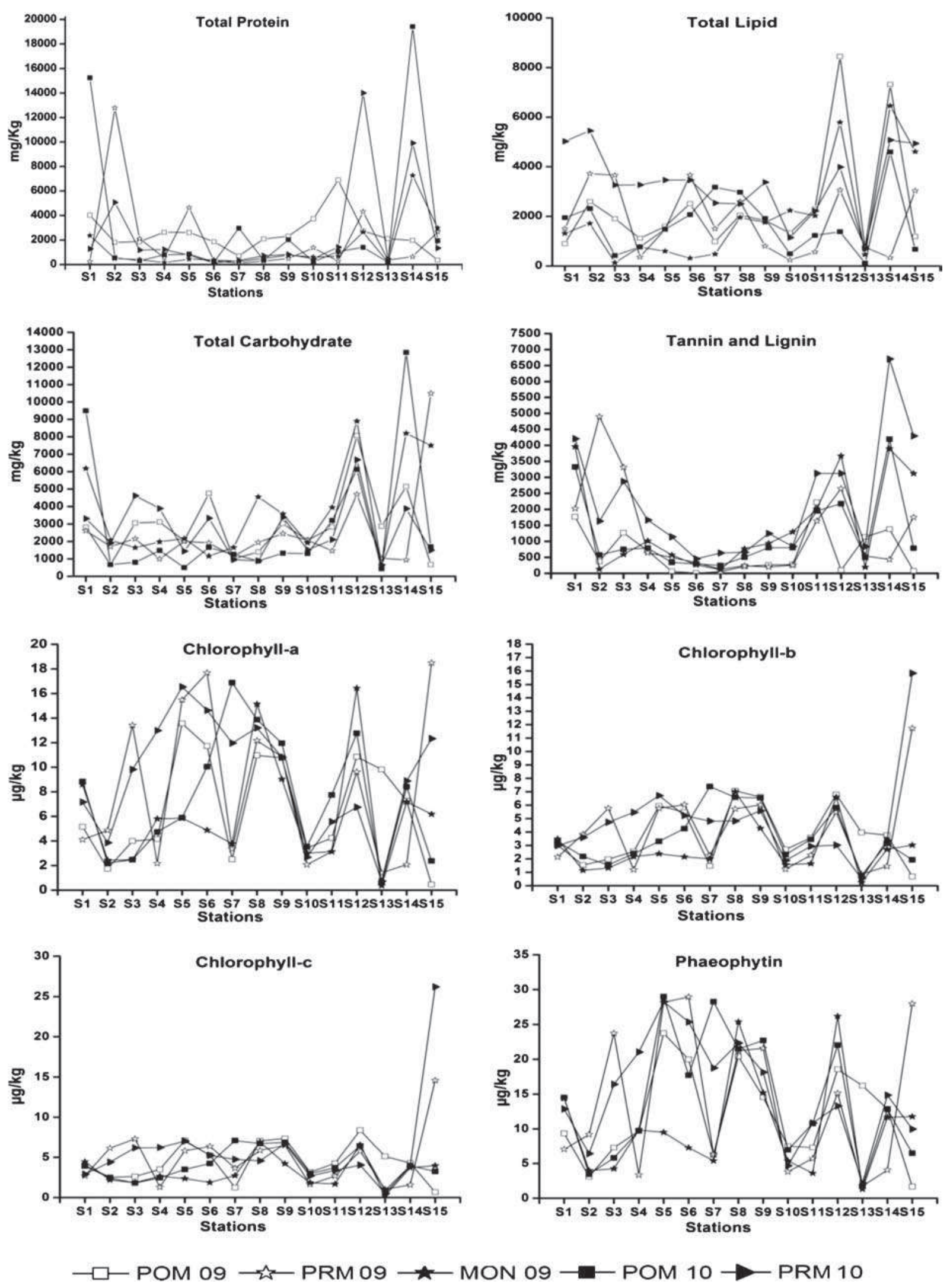

Figure 3. Seasonal and spatial variations of tannin and lignin, total carbohydrate, total proteins, total lipids and chlorophyll pigments in surface sediment of Cochin estuarine system. 

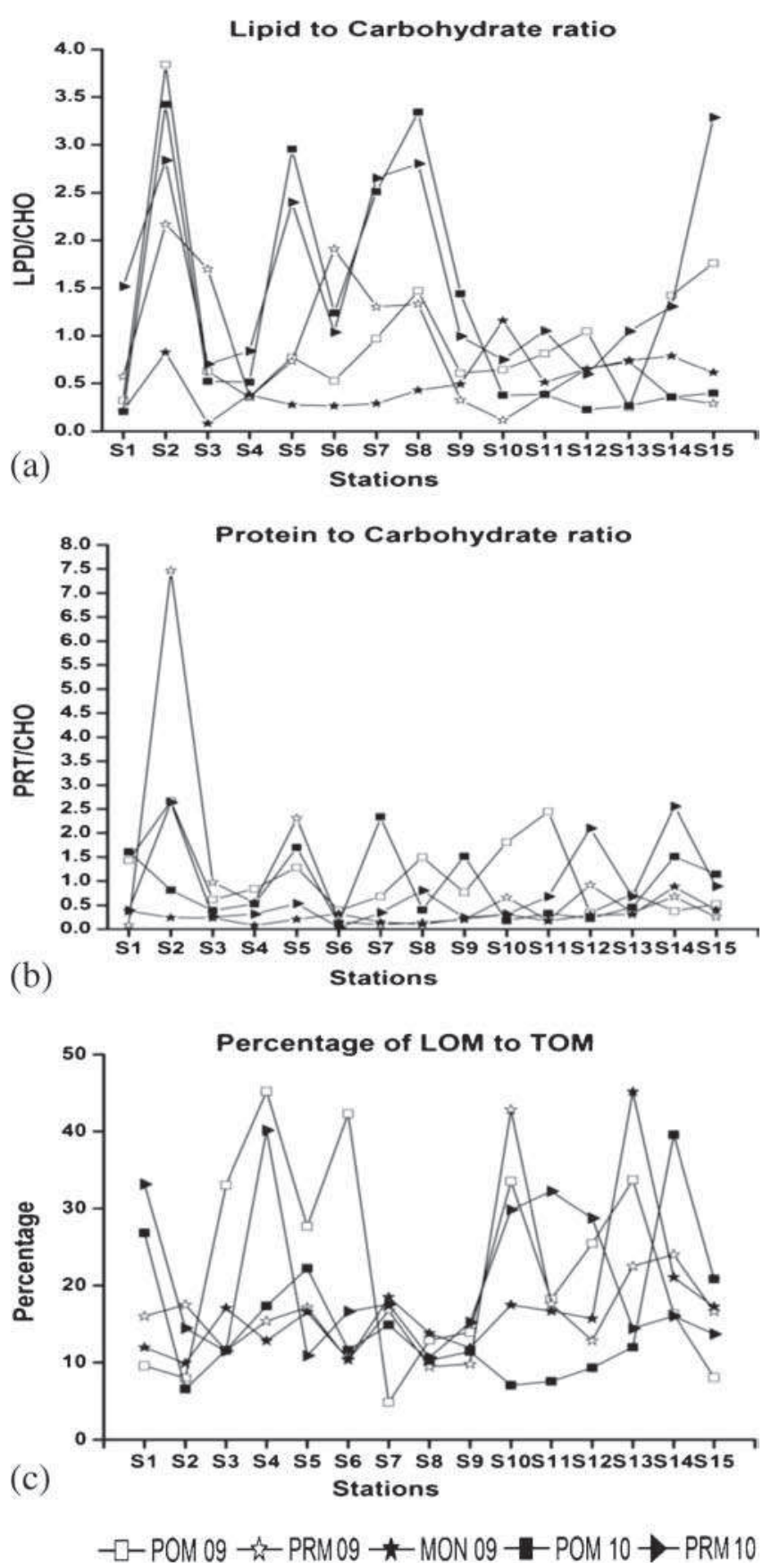

Figure 4. Variations of lipid to carbohydrate ratio (a), protein to carbohydrate ratio (b), and percentage contribution of LOM to TOM (c) in surface sediments of the study area.

chl-c: $0.23-26.20 \mu \mathrm{g} / \mathrm{kg}$. This pigment concentrations were very comparable with the other estuaries (table 4). Spatial variation of chlorophyll pigments in the surface sediments was attributed to light availability and DO content in the water column (Kowalewska and Szymczak 2001; Kowalewska et al. 2004; Moreno and Niell 2004). Chl-a content exhibited pronounced seasonal variation with its maximum in the pre-monsoon and minimum during the monsoon season. A highly significant positive correlation (table 2) with fine-grained fraction (silt and clay) implied the effect of grain size on the pigment distribution in sediments (Colijn and Dijkema 1981; Moreno and Niell 2004). Bulk quantities of suspended particulate matter leached via river run-off, and enhanced the water column turbidity leading to reduction in solar radiation. Autochthonous water column input contributes chlorophyll to sediments (Szymczak-Zyła and Kowalewska 2007). The depleted levels of pigments during monsoon might also be due to high flushing which results in the faster removal of phytoplankton towards the coastal regions (Jyothibabu et al. 2006). Concentration of chlorophyll pigments in the sediments followed the trend: chl $-c>$ chl $-a>$ chl- $b$ (figure 3 ). The ratio of chl- $a$ to phaeopigments showed a minimum value at fishing zone (S5; $0.20 \mu \mathrm{g} / \mathrm{kg} ;$ POM10) and maximum at the industrial zone (S15; $1.24 \mu \mathrm{g} / \mathrm{kg} ; \mathrm{PRM} 10)$.

In most of the stations, the estimated chl- $a$ to phaeopigments ratio were low $(<1)$ and the ratio of chl- $a /$ (chl- $a+$ phaeopigments) ranged from 0.17 to 0.55 . Phaeopigments, the early breakdown product of chl- $a$ degrade more slowly and the concentration of chl- $a$ to phaeopigments ratio could suggest the relative rate and time-frame of phytoplankton deposition. Combined use of these ratios suggested a rapid and recent deposition of phytoplankton in sediments (Josefson and Conley 1997; Hagy et al. 2005). Similarly, the close relationship (table 2) between biochemical constituents (CHO and LPD) and chloropigments in the sediments pointed out a higher contribution of phytobenthic populations and their associated detritus to the bulk organic matter (Fabiano and Danovaro 1994; Danovaro et al. 2000).

Aromatic polycyclic phenolic compounds such as tannin and lignin are synthesised by the vascular plants (Finar 1976; Field and Lettinga 1987; Hernes and Hedges 2000) and are transported to sedimentary environments via terrestrial run-off. Tannin and lignin form a significant fraction of refractory $\mathrm{OM}$ and its estimation provides valuable information on the input of terrestrially-derived organic detritus in marine systems (Lin et al. 2006). Tannin and lignin content displayed strong spatial and seasonal variations $(\mathrm{p}<0.01)$ with a range of 7.18 to $6706 \mathrm{mg} / \mathrm{kg}$. The high tannin and lignin content recorded in the study area (figure 3 ) might be originating from terrestrial vascular plant debris. The abundance of these unique phenolic compounds has already been published (Renjith et al. 2012; Akhil et al. 2013).

The assessment of the nature of organic matter, whether it is labile or refractory is a crucial step in organic geochemical studies and can be studied employing different biochemical compounds. The sum of all proteins, carbohydrates and lipids are defined as labile (Danovaro et al. 1993; Cividanes 
Table 2. Correlation between sedimentary parameters in the study region.

\begin{tabular}{|c|c|c|c|c|c|c|c|c|c|c|c|c|c|c|}
\hline Parameters & Sand & Clay & Silt & TOC & $\mathrm{N}$ & $\mathrm{S}$ & PRT & $\mathrm{CHO}$ & LPD & Chl- $a$ & Chl- $b$ & Chl- $c$ & Phe & $\mathrm{TL}$ \\
\hline Sand & 1 & & & & & & & & & & & & & \\
\hline Clay & -0.78 & 1 & & & & & & & & & & & & \\
\hline Silt & -0.93 & 0.49 & 1 & & & & & & & & & & & \\
\hline TOC & -0.33 & 0.25 & 0.32 & 1 & & & & & & & & & & \\
\hline $\mathrm{N}$ & -0.18 & 0.2 & 0.13 & 0.41 & 1 & & & & & & & & & \\
\hline S & -0.43 & 0.38 & 0.37 & 0.58 & 0.6 & 1 & & & & & & & & \\
\hline PRT & -0.07 & 0.03 & 0.08 & 0.52 & 0.42 & 0.4 & 1 & & & & & & & \\
\hline $\mathrm{CHO}$ & -0.19 & 0.25 & 0.12 & 0.68 & 0.48 & 0.48 & 0.6 & 1 & & & & & & \\
\hline LPD & -0.41 & 0.46 & 0.3 & 0.62 & 0.47 & 0.56 & 0.37 & 0.54 & 1 & & & & & \\
\hline Chl- $a$ & -0.41 & 0.39 & 0.34 & 0.41 & 0.27 & 0.54 & 0.07 & 0.35 & 0.44 & 1 & & & & \\
\hline Chl- $b$ & -0.25 & 0.25 & 0.2 & 0.41 & 0.16 & 0.39 & 0.04 & 0.27 & 0.45 & 0.83 & 1 & & & \\
\hline Chl- $c$ & -0.13 & 0.12 & 0.011 & 0.38 & 0.11 & 0.27 & 0.07 & 0.24 & 0.43 & 0.66 & 0.95 & 1 & & \\
\hline Phe & -0.4 & 0.38 & 0.33 & 0.34 & 0.25 & 0.48 & 0.06 & 0.3 & 0.37 & 0.94 & 0.72 & 0.52 & 1 & \\
\hline $\mathrm{TL}$ & -0.05 & -0.04 & 0.1 & 0.5 & 0.42 & 0.35 & 0.61 & 0.52 & 0.49 & 0.12 & 0.17 & 0.23 & 0.05 & 1 \\
\hline
\end{tabular}

Note: Correlation significant at 0.01 level are shown in bold and correlation significant at 0.05 level are shown in italics.

Table 3. Trophic status of the study area (season-wise).

\begin{tabular}{|c|c|c|c|c|c|}
\hline Zone & POM09 & PRM09 & MON09 & POM10 & PRM10 \\
\hline Riverine & Eutrophic & Eutrophic & Oligotrophic & Eutrophic & Eutrophic \\
\hline Fishing & Mesotrophic & Mesotrophic & Oligotrophic & Mesotrophic & Mesotrophic \\
\hline Sewage/tourism influenced & Mesotrophic & Mesotrophic & Mesotrophic & Mesotrophic & Eutrophic \\
\hline Industrial & Eutrophic & Eutrophic & Eutrophic & Mesotrophic & Eutrophic \\
\hline
\end{tabular}

and Souza 2003). Labile fraction denotes the easily assimilable portion of organic matter that is easily available for the use of aquatic organisms including benthos. The labile organic matter (LOM) content in sediments recorded a remarkable variation from 746.47 to $36847 \mathrm{mg} / \mathrm{kg}$; its contribution to TOM varied from 4.85 to $45.19 \%$. The river and industrial zones (figure 4c) indicated higher contribution of LOM to TOM and the elevated values establish enhanced productivity, coupled with external supply of terrigineous materials. Previous studies from the CES recorded contribution of LOM to TOM ranging from $9.43-31.10 \%$ (Joseph et al. 2008), suggested the fact that a significant fraction of TOM represented refractory material.

Characterization of trophic state in aquatic ecosystems is necessary for understanding food web linkages as well as biogeochemical features and subsequently water quality (Smith 2003). Like other ecosystems, estuaries have biotic communities that depend on carbon resources to fuel food webs and maintain the organisms that live in them. Generally trophic status are catagorised as oligotrophic (unproductive), mesotrophic (intermediate productivity) and eutrophic (highly productive). Trophic state can be influenced by light, external carbon source, nutrients, hydrology and food web structure (Dodds and Cole 2007). The indiscriminate and unscientific application of fertilisers, industrial input and domestic sewage has introduced bulk quantities of nutrients into the estuary, which affected the food web structure and alterations in trophic state. Trophic state assessment was carried out based on biopolymeric carbon (BPC) and the algal contribution to $\mathrm{BPC}$ (Pusceddu et al. 2011). This methodology categorise the estuarine stations as follows: eutrophic (BPC $>3 \mathrm{mgC} / \mathrm{g}$, algal fraction $<12 \%$ of $\mathrm{BPC})$, mesotrophic $(\mathrm{BPC}=1-3 \mathrm{mgC} / \mathrm{g}$, algal fraction = $12-25 \%$ of BPC) and oligotrophic (BPC $<1 \mathrm{mgC} / \mathrm{g}$, algal fraction $>25 \%$ of $\mathrm{BPC}$ ). Algal contribution to BPC was calculated as the percentage of chl- $a$ to $\mathrm{BPC}$ concentrations, after converting chl- $a$ concentration into carbon equivalents (chl carbon) using a mean value of 40 (Pusceddu et al. 2009). The ratio of chl carbon to chl- $a$ in sediments usually vary from 10 to higher than 100 (De Jonge 1980) and using this mean value, comparison of the present data with literature information from other marine and coastal areas was possible (Pusceddu et al. 1999, 2009, 2011).

Based on these criteria, present investigation ranked the stations as mesotrophic or eutrophic. Seasonal variation was recorded in the benthic trophic state of the estuarine system. The riverine (except MON09) and industrial zones (except POM10) were eutrophic. Mesotrophic character was observed in the fishing (except MON09) and 
Table 4. Comparison of present study with bulk sedimentary parameters from different estuaries in the world.

\begin{tabular}{|c|c|c|c|c|c|c|c|}
\hline Study region & LPD (mg/kg) & PRT (mg/kg) & $\mathrm{CHO}(\mathrm{mg} / \mathrm{kg})$ & Pigments $(\mu \mathrm{g} / \mathrm{kg})$ & $\delta^{13} \mathrm{C}(\% 0)$ & $\mathrm{TOC} / \mathrm{N}$ & Reference \\
\hline $\begin{array}{l}\text { South-eastern } \\
\text { Arabian sea }\end{array}$ & $900-5100$ & $100-7300$ & $400-3500$ & - & - & - & Ramya et al. (2013) \\
\hline $\begin{array}{l}\text { East coast } \\
\text { of India }\end{array}$ & - & - & $2800-4710$ & - & -23.2 to -19.6 & $15-23$ & Kumar et al. (2013) \\
\hline Cochin estuary & $41.50-3160$ & $24.48-2600$ & $166-6339$ & $\begin{array}{c}\text { Chl- } a \text { : } 220-37800 \\
\text { Chl- } b \text { : BDL-16710 } \\
\text { Chl-c: BDL-8970 } \\
\text { Phe: } 360-64520\end{array}$ & -28.25 to -24.73 & $0.73-33.62$ & Renjith et al. (2012) \\
\hline $\begin{array}{l}\text { Rio de la Plata } \\
\text { estuary }\end{array}$ & $500-8350$ & $1080-16370$ & $290-8860$ & $\begin{array}{l}\text { Chl- } a: 0.1 * 10^{-6}-11.6 * 10^{-6} \\
\text { Phe: } 1.7 * 10^{-6}-35 * 10^{-6}\end{array}$ & - & - & Venturini et al. (2012) \\
\hline Cochin estuary & - & - & - & - & -27.5 to -21.7 & $7-21$ & Gireeshkumar et al. (2012) \\
\hline $\begin{array}{l}\text { Pichavaram mangrove - } \\
\text { estuarine sediments, } \\
\text { India }\end{array}$ & - & - & - & - & -23.2 to 5.1 & 12.3 & Ranjan et al. (2011) \\
\hline Pearl river estuary & - & - & - & - & -25.1 to -21.3 & $6.50-13.30$ & He et al. (2010) \\
\hline $\begin{array}{l}\text { Pearl river delta } \\
\text { and estuary }\end{array}$ & - & - & - & - & -25 to -21 & $6.8-15.2$ & Fengling et al. (2010) \\
\hline Pichavaram estuary & - & - & - & - & -28.92 to -25.34 & - & Prasad and Ramanathan (2008) \\
\hline Cochin estuary & $312-2815$ & 205-1924 & $250-1229$ & - & - & $4.80-10.62$ & Joseph et al. (2008) \\
\hline Mundaka estuary & $300-5000$ & BDL-16700 & $200-5700$ & - & - & - & Cotano and Villate (2006) \\
\hline Yangtze estuary, China & - & - & - & $\begin{array}{l}\text { Chl- } a: 0.05 * 10^{-6} \\
\quad \text { to } 8.01 * 10^{-6}\end{array}$ & -29.8 to -26.0 & $1.6-5.5$ & Liu et al. (2006) \\
\hline Chunnambar, India & - & - & - & - & -23.3 to -24.5 & - & Bouillon et al. (2004) \\
\hline Winyah Bay, SC, USA & - & - & - & - & -28 to -23 & $5-45$ & Goni et al. (2003) \\
\hline $\begin{array}{l}\text { Harney river estuary, } \\
\text { Florida }\end{array}$ & - & - & - & - & -28.9 to -19.0 & - & Hernandez et al. (2001) \\
\hline $\begin{array}{l}\text { Lower St. Lawrence } \\
\text { estuary }\end{array}$ & $820-1470$ & $110-400$ & $7580-10700$ & - & - & - & Colombo et al. (1996) \\
\hline $\begin{array}{l}\text { River estuary } \\
\text { (Tyrrhenian Sea) }\end{array}$ & $2.9-12.6$ & $250-1670$ & $350-1890$ & $\begin{array}{c}\text { Chl- } a: \text { 90-1500 } \\
\text { Phe: } 30-1900\end{array}$ & - & - & Fabiano and Danovaro (1994) \\
\hline Cochin estuary & $115.29-8450$ & $110.67-19420$ & $434.19-12839$ & $\begin{array}{l}\text { Chl- } a: 0.36-18.49 \\
\text { Chl- } b: 0.24-16 \\
\text { Chl-c: } 0.23-26.20 \\
\text { Phe: } 1.33-28.98\end{array}$ & -24.73 to -46.43 & $0.57-26.75$ & Present study \\
\hline
\end{tabular}


sewage/tourism influenced zones (except PRM10) during the investigation (table 3 ) period. The wide fluctuations in trophic status could be attributed to the input of large quantities of allochthonous OM into the estuary (Thomson 2002; Balachandran et al. 2003; Babu et al. 2006; Thottathil et al. 2008; Martin et al. 2010). The estuary receives heavy fresh water influx during summer monsoon (Srinivas et al. 2003) and the consequent run-off results in the large amount of OM to this estuary (Balachandran et al. 2003). Moreover, enriched levels of dissolved and particulate OM have been recorded from the central part of the estuary (Martin et al. 2010) which clearly reflected sewage input from various outlets of Cochin city. The eutrophication induced changes in the benthic community structure was also recently reported by Martin et al. (2011). Furthermore, the alteration in trophic status directly affects the ecological balance and biogeochemical cycles of carbon and associated elements.

In order to achieve more information on the sources of the OM and their transformation processes, elemental and stable carbon isotope ratios were used (Gearing et al. 1977; Tan et al. 1991; Thornton and Mc-Manus 1994; Meyers 1997; Mitchell et al. 1997; Andrews et al. 1998; Graham et al. 2001; Bianchi et al. 2002). TOC/N ratios have been used as efficient tracers of OM based on the fact that marine and terrestrial derived $\mathrm{OM}$ have a TOC/N ratio of 5-8 and $>15$, respectively
(Meyers 1997). Apart from other indices, TOC/N ratio displayed its minimum (0.57) at $\mathrm{S} 10$ and maximum (26.75) at S7. Intermediate values of $\mathrm{TOC} / \mathrm{N}$ ratio signalled a mixed contribution of both autochthonous and terrestrial OM to the estuarine sediments (Muri et al. 2004) and the data was comparable with previous studies (table 4).

The application of $\delta^{13} \mathrm{C}$ was based on the assumption that marine organic matter typically possesses values for terrestrial C3 plants ( -26 $-28 \%$ ) and phytoplankton (-19-22\%) (Gearing et al. 1977; Meyers 1997; Bianchi et al. 2002). $\delta^{13} \mathrm{C}$ of bulk organic matter obtained in the present investigation varied from -32.34 to $-25.39 \%$. The riverine (S1, S2, S3, S4) and industrial zones (S13, $\mathrm{S} 14$ and $\mathrm{S} 15)$ recorded more depleted $\delta^{13} \mathrm{C}$ values, suggesting a major contribution of terrestrial higher plant debris to sedimentary organic matter. Biochemical constituents and bulk organic matter parameters like stable carbon isotope ratios estimated in present investigation were in good agreement with earlier reports (table 4 ).

The statistical analysis (table 2 ) revealed a positive correlation between fine grained fractions (silt and clay) with various biochemical constituents. The strong relationships exhibited by TOC, N and $\mathrm{S}$ with CHO, PRT, LPD and other variables pointed towards the adsorption and diagenetic process controlling the distribution of the biochemical components in the sedimentary environment. Interrelationship among the biochemical components

\section{CCA Map / Symmetric \\ (axes F1 and F2: $91.17 \%$ )}

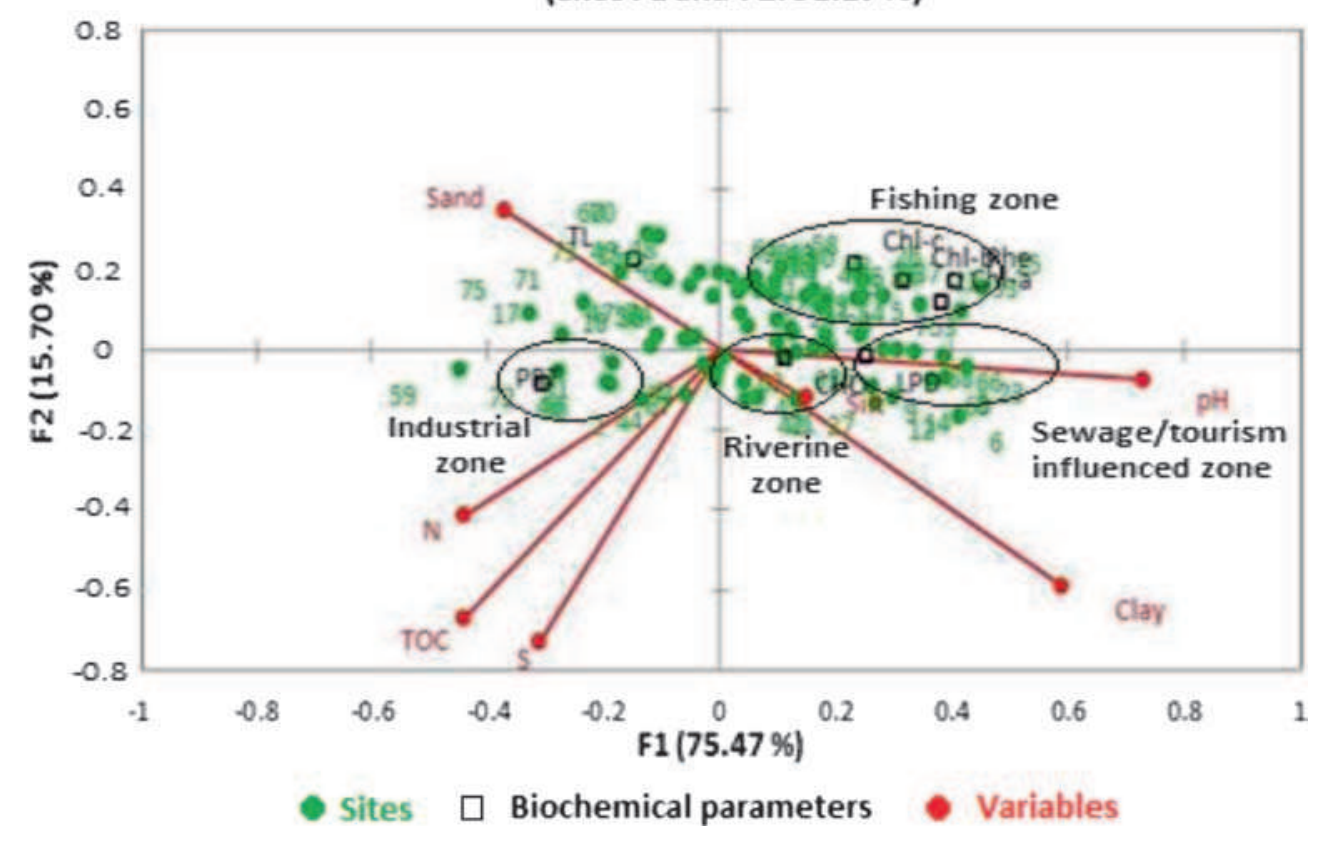

Figure 5. Canonical correspondence analysis showing the distribution and association of various biochemical components studied in the Cochin estuarine system. 
with each other points towards a common source and similar behaviour in the estuarine environment. Significant correlation of carbohydrates with chloropigments in sediments pointed out the contribution of phytobenthic populations and derived detritus to the total OM.

Canonical correspondence analysis (CCA), a multivariate extension of weighed averaging ordination was used in the present study to relate the distribution of different biochemical components to general sedimentary parameters. The length of the arrows (sedimentary parameters) and their orientation indicates their relative importance and approximate correlations to the axes. The arrows point out in the direction of increase of the sedimentary parameters.

Figure 5 revealed higher concentration of phaeopigments in the riverine (S3-MON09), fishing (S7-PRM09, S6- and S7-POM10, S5-PRM10), sewage/tourism influenced (S10-PRM09 and POM 10) and industrial zones (S11, S13-PRM09). Similarly lipids were more concentrated in fishing (S6-PRM10) and sewage/tourism influenced zones (S8-PRM09 and PRM10, S9-PRM10). Carbohydrates were more abundant at the riverine $(\mathrm{S} 1$, S2-PRM10) and fishing zones (S6-MON09). Proteins were concentrated at riverine (S1-POM10) and industrial zones (S12-PRM10, S15-PRM09). Further, CCA analysis established the fact that, protein distribution was influenced by changes in N, S and TOC (figure 5); while phaeopigments did not show any relation with sedimentary parameters. It could also be deduced that the dispersal pattern of carbohydrates and lipids in sediments were controlled by $\mathrm{pH}$ and fine grained fractions (silt and clay) of the sediment.

\section{Conclusion}

Texture analysis implied the predominance of silt and clay in the estuarine sediments. The TOC/S ratios in the majority of the stations inferred periodic anoxia. The high lipid content and LPD/CHO ratio not only reflected the quality of $\mathrm{OM}$ to support benthic fauna, but a better preservation of lipid compounds in the sedimentary environment. Lower PRT/CHO ratio suggested a detrital heterotrophic environment in the study area. Biopolymeric carbon and the algal contribution to BPC provided important information on the better understanding of the trophic status. Estimated TOC/N ratios implied the combined input of both terrestrial and autochthonous organic matter to sediments. The more depleted $\delta^{13} \mathrm{C}$ value of bulk sedimentary organic matter implied terrestrial input of vascular plant debris, which was supported by higher concentrations of tannin and lignin. Chl- $a /$ phaeopigment ratio and chl- $a /$ (chl$a+$ phaeopigment) ratio, revealed rapid and recent deposition of phytoplankton detritus to sediments. Grain size, nutrients and total organic carbon content had substantial influence on the distribution of the biochemical composition of sediments. Canonical correspondence analysis revealed that the association of variables and their distribution/accumulation trends within the various zones of the estuarine ecosystem. Molecular level characterization (biomarker approach) is recommended to achieve more specific information on the degradation status of OM in this complex ecosystem.

\section{Acknowledgements}

The authors gratefully acknowledge the financial support given by the Ministry of Earth Sciences (MoES), Govt. of India and also thank the Head, Department of Chemical Oceanography, School of Marine Sciences, Cochin University of Science and Technology for providing facilities. The authors express their heartfelt gratitude to Associate Editor and anonymous reviewers for their scientific encouragement and constructive comments that improved the paper.

\section{References}

Andrews J E, Greenaway A M and Dennis P F 1998 Combined carbon isotope and $\mathrm{C} / \mathrm{N}$ ratios as indicators of source and fate of organic matter in a poorly flushed, tropical estuary; Hunts Bay, Kingston Harbour, Jamaica; Estuar. Coast. Shelf Sci. 46 743-756.

Aneeshkumar N and Sujatha C H 2012 Biomarker pigment signatures in Cochin back water system - A tropical estuary south west coast of India; Estuar. Coast. Shelf Sci. 99 182-190.

Akhil P S, Manju P Nair and Sujatha C H 2013 Core sediment biogeochemistry in specific zones of Cochin Estuarine System (CES); J. Earth Syst. Sci. 122 1557-1570.

APHA 1995 Standard methods for the examination of water and waste water; American Public Health Association, 19th edn, Washington.

Babu M T, Kesavadas V and Vethamony P 2006 BOD-DO modeling and water quality analysis of a waste water out fall off Kochi, west coast of India; Environ. Int. 32 165-173.

Balachandran K K, Thresiamma J, Maheswari N, Sankaranarayanan N, Kesavadas V and Sheeba P 2003 Geochemistry of surficial sediments along the central southwest coast of India; J. Coast. Res. $19664-683$.

Balachandran K K, Lalu Raj C M, Nair M, Joseph T, Sheeba P and Venugopal P 2005 Heavy metal accumulation in a flow restricted, tropical estuary; Estuar. Coast. Shelf Sci. 65 361-370.

Balachandran K K, Reddy G S, Revichandran C, Srinivas K, Vijayan P R and Thottam T J 2008 Modeling of tidal hydrodynamics for a tropical ecosystem with implications for pollutant dispersion (Cochin Estuary, South India); Ocean. Dyn. 58 76-88. 
Balasubramanian R, Tamilarasan R, Babu $\mathrm{R}$ and Varadharajan D 2012 Biochemical changes with influence of nutrient in polychaetes Laeonereis ankyloseta, south east coast of India; Arch. Appl. Sci. Res. 4 1869-1879.

Barnes H and Blackstock J 1973 Estimation of lipids in marine animals and tissues: Detailed investigation of the sulphosphovanillin method for 'total' lipids; J. Exp. Mar. Biol. Ecol. 12 103-118.

Bianchi T S, Engelhaupt E and Mckee B A 2002 Do sediments from coastal sites accurately reflect time trends in water column phytoplankton? A test from Himmerfjarden Bay (Baltic Sea proper); Limnol. Oceanogr. 47 1537-1544.

Bligh E G and Dyer W J 1959 A rapid method of total lipid extraction and purification; Can. J. Biochem. Phys. 37 911-917.

Bouillon S, Moens T, Koedam N, Dahdouh-Guebas F, Baeyens W and Dehairs F 2004 Variability in the origin of carbon substrates for bacterial communities in mangrove sediments; FEMS Microbiol. Ecol. 49 171-179.

Borsheim K Y, Myklestad S M and Sneli J A 1999 Monthly profiles of DOC, mono and poly saccharides at two locations in the Trondheimsfjords (Norway) during two years; Mar. Chem. 63 255-272.

Burdige D J, Skoog A and Gardner K 2000 Dissolved and particulate carbohydrates in contrasting marine sediments; Geochim. Cosmochim. Acta 64 1029-1041.

Cartes J E, Gremare A, Maynou F, Villora-Moreno S and Dinet A 2002 Bathymetric changes in the distributions of particulate organic matter and associated fauna along a deep-sea transect down the Catalan sea slope (northwestern Mediterranean); Prog. Oceanogr. 53 29-56.

Cifuentes L A 1991 Spatial and temporal variations in terrestrially derived organic matter from sediments of the Delaware estuary; Estuaries 14 414-419.

Cividanes F J and Souza V P 2003 Exigências térmicas e tabelas de vida de fertilidade de Myzus persicae (Sulzer) (Hemiptera: Aphididae) em laboratório; Neotrop. Entomol. 32 413-419.

Cividanes S, Incera M and Lopez J 2002 Temporal variability in the biochemical composition of sedimentary organic matter in an intertidal flat of the Galician coast (NW Spain); Oceanol. Acta 25 1-12.

Cloern J E 2001 Our evolving conceptual model of the coastal eutrophication problem; Mar. Ecol. Prog. Ser. $210223-253$.

Colijn F C and Dijkema K S 1981 Species composition of benthic diatoms and distribution of chlorophyll- $a$ on an intertidal flat in the Dutch Wadden Sea; Mar. Ecol. Prog. Ser. 4 9-21.

Colombo J C, Silverberg N and Gearing J N 1996 Biogeochemistry of organic matter in the Laurentian trough, II. Bulk composition of the sediments and relative reactivity of major components during early diagenesis; Mar. Chem. $51295-314$.

Cotano U and Villate F 2006 Anthropogenic influence on the organic fraction of sediments in two contrasting estuaries: A biochemical approach; Mar. Pollut. Bull. 52 404-414.

Cowie G L and Hedges J I 1984 Carbohydrate sources in a coastal marine environment; Geochim. Cosmochim. Acta $482075-2087$.

Danovaro R, Fabiano M and Della Croce N 1993 Labile organic matter and microbial biomasses in deep-sea sediments (Eastern Mediterranean Sea); Deep Sea. Res. 40 953-965.

Danovaro R 1996 Detritus-bacteria-meofauna interactions in a seagrass bed (Posidonia oceanica) of the NW Mediterranean; Mar. Biol. 127 1-13.
Danovaro R, Marrale D, Della Croce N, Parodi P and Fabiano M 1999 Biochemical composition of sedimentary organic matter and bacterial distribution in the Aegean Sea: Trophic state and pelagic-benthic coupling; J. Sea Res. 42 117-129.

Danovaro R, Marrale D, Dell'Anno A, Della Croce N, Tselepides A and Fabiano M 2000 Bacterial response to sea seasonal changes in labile organic matter composition on the continental shelf and bathyal sediments of the Cretan Sea; Prog. Oceanogr. 46 345-366.

Dayala V T, Salas P M and Sujatha C H 2014 Spatial and seasonal variations of phytoplankton species and their relationship to physicochemical variables in the Cochin estuarine waters, southwest coast of India; IJMS $\mathbf{4 3}$ 937-947.

De Jonge V N 1980 Fluctations in the organic carbon to chlorophyll-a ratios for estuarine benthic diatom populations; Mar. Ecol. Prog. Ser. 2 345-353.

Dell'Anno A, Fabiano M, Mei M L and Danovaro R 2000 Enzymatically hydrolysed protein and carbohydrates polls in deep-sea sediments: Estimates of the available fraction and methodological considerations; Mar. Ecol. Prog. Ser. 196 15-23.

Dell'Anno A, Mei M L, Pusceddu A and Danovaro R 2002 Assessing the trophic state and eutrophication of coastal marine systems. A new approach based on the biochemical composition of sediment organic matter; Mar. Pollut. Bull. 44 611-622.

Deepulal P M, Gireesh Kumar T R and Sujatha C H 2012 Behaviour of REEs in a tropical estuary and adjacent continental shelf of southwest coast of India: Evidence from anomalies; J. Earth Syst. Sci. 121 1215-1227.

Dubois M, Gilles K A, Hamilton J K, Rebers P A and Smith F 1956 Colorimetric method for determination of sugars and related substances; Anal. Chem. 28 350356.

Duineveld G C A, de Wilde P A W J, Berghuis E M, Kok A, Tahey T and Kromkamp J 1997 Benthic respiration and standing stock on two contrasting continental margins in the western Indian Ocean: The Yemen-Somali upwelling region and the margin off Kenya; Deep Sea Res. 44 1293-1317.

Dodds W K and Cole J J 2007 Expanding the concept of trophic state in aquatic ecosystems: It's not just the autotrophs; Aquat. Sci. 69 427-439.

Fabiano M and Danovaro R 1994 Composition of organic matter in sediments facing a river estuary (Tyrrhenian Sea): Relationships with bacteria and microphytobenthic biomass; Hydrobiologia 277 71-84.

Fabiano M, Danovaro R and Fraschetti S 1995 Temporal trend analysis of the elemental composition of the sediment organic matter in subtidal sandy sediments of the Ligurian Sea (NW Mediterranean): A three years study; Cont. Shelf Res. 15 1453-1469.

Fabiano M and Pusceddu A 1998 Total hydrolizable particulate organic matter (carbohydrates, proteins, and lipids) at a coastal station in Terra Nova Bay (Ross Sea, Antarctica); Polar Biol. 19 125-132.

Fengling $\mathrm{Yu}$, Yongqiang Zong, Jeremy M L, Guangqing Huang, Melanie J L, Christopher Kendrick, Angela L L and Wyss W S Y 2010 Bulk organic $\delta^{13} \mathrm{C}$ and $\mathrm{C} / \mathrm{N}$ as indicators for sediment sources in the Pearl River delta and estuary, southern China; Estuar. Coast. Shelf Sci. $\mathbf{8 7}$ 618-630.

Fichez R 1991 Composition and fate of organic matter in submarine cave sediments: Implications for the biogeochemical cycle of organic carbon; Oceanol. Acta 14 369-377. 
Field J A and Lettinga G 1987 The methanogenic toxicity and anaerobic degradability of a hydrolysable tannin; Water Res. 21 367-374.

Finar I L 1976 Organic chemistry, Vol. 1, Longman, Singapore.

Folk R L 1974 The petrology of sedimentary rocks, Austin, Tex., Hemphill Publishing Co., 184p.

Gearing P J, Plucker F E and Parker P L 1977 Organic carbon stable isotope ratios of continental margin sediments; Mar. Chem. 5 251-266.

Gireeshkumar T R, Deepulal P M and Chandramohanakumar N 2012 Distribution and sources of sedimentary organic matter in a tropical estuary, south west coast of India (Cochin estuary): A baseline study; Mar. Pollut. Bull. 66 239-245.

Gopalan U K, Doyil T, Vengayil P, Udaya V and Krishnankutty M 1983 The shrinking backwaters of Kerala; J. Mar. Biol. Assoc. India 25 131-141.

Goni M A, Maria J T and David W P 2003 Sources and distribution of organic matter in a river-dominated estuary (Winyah Bay, SC, USA); Estuar. Coast. Shelf Sci. 57 1023-1048.

Graf G 1989 Benthic-pelagic coupling in a deep-sea benthic community; Nature 341 437-439.

Graham M C, Eaves M A, Framer J G, Dobson J and Fallick A E 2001 A study of carbon and nitrogen stable isotope and elemental ratios as potential indicators of source and fate of organic matter in sediments of the Forth estuary, Scotland; Estuar. Coast. Shelf Sci. 52 375-380.

Grant J and Hargrave B T 1987 Benthic metabolism and the quality of sediment organic carbon; Biol. Oceanogr. 4 243-263.

Gremare A, Amouroux J M, Charles F, Dinet A, RiauxGobin C, Baudart J, Medernach L, Bodiou J Y, Vétion G, Colomines J C and Albert P 1997 Temporal changes in the biochemical composition and nutritional value of the particulate organic matter available to surface depositfeeders: A two year study; Mar. Ecol. Prog. Ser. 150 195-206.

Gremare A, Medernach L, deBovée F, Amoroux J M, Vétion G and Albert P 2002 Relationships between sedimentary organics and benthic meiofauna on the continental shelf and the upper slope of the Gulf of Lions (NW Mediterranean); Mar. Ecol. Prog. Ser. 234 85-94.

Hagy J D, Boynton W R and Jasinski D A 2005 Modeling phytoplankton deposition to Chesapeake Bay sediments during winter-spring: Interannual variability in relation to river flow; Estuar. Coast. Shelf Sci. 62 25-40.

He B, Dai M, Huang W, Liu Q, Chen H and Xu L 2010 Sources and accumulation of organic carbon in the Pearl River Estuary surface sediment as indicated by elemental, stable carbon isotopic, and carbohydrate compositions; Biogeosci. 7 3343-3362.

Hernandez M E, Mead R, Peralba M C and Jaffe R 2001 Origin and transport of $n$-alkane-2-ones in a subtropical estuary: Potential biomarkers for sea grass derived organic matter; Org. Geochem. 32 21-32.

Hernes P J and Hedges J I 2000 Determination of condensed tannin monomers in environmental samples by capillary gas chromatography of acid depolymerization extracts; Anal. Chem. 72 5115-5124.

Jacob J, Chandramohanakumar N, Jayaraj K A, Raveendran T V, Balachandran K K, Joseph T, Nair M, Achuthankutty C T, Nair K K C, Rejomon George and Zeena P R 2008 Biogeochemistry of the surficial sediments of the western and eastern continental shelves of India; J. Coast. Res. 24 1240-1248.

Jacob J, Jayaraj K A, Rehman H H, Chandramohanakumar N, Balachandran K K, Raveendran T V, Joseph T, Nair
M and Achuthankutty C T 2009 Biogeochemical characteristics of the surface sediments along the western continental shelf of India; Chem. Ecol. 25 135-149.

Jayaprakash A A 2002 Long term trends in rainfall, sea level and solar periodicity: A case study for forecast of Malabar sole and oil sardine fishery; J. Mar. Biol. Assoc. India 44 $163-175$.

Josefson A B and Conley D J 1997 Benthic response to a pelagic front; Mar. Ecol. Prog. Ser. 147 49-62.

Joseph M M, Ratheesh Kumar C S, GireeshKumar T R, Renjith K R and Chandramohanakumar N 2008 Biogeochemistry of surficial sediments in the intertidal systems of a tropical environment; Chem. Ecol. 24 $247-258$.

Jyothibabu R, Madhu N, Jayalakshmi K, Balachandran K, Shiyas C, Martin G and Nair K 2006 Impact of freshwater influx on microzooplankton mediated food web in a tropical estuary (Cochin backwaters - India); Estuar. Coast. Shelf Sci. 69 505-518.

Kowalewska G and Szymczak M 2001 Influence of selected abiotic factors on the decomposition of chlorophylls; Oceanologia 43 315-328.

Kowalewska G, Wawrzyniak-Wydrowska B and SzymczakZyła M 2004 Chlorophyll- $a$ and its derivatives in sediments of the Odra estuary as a measure of its eutrophication; Mar. Pollut. Bull. 49 148-153.

Kumar B S K, Sarma V V S S and Krishna M S 2013 Distribution of biochemical constituents in the surface sediments of western coastal Bay of Bengal: Influence of river discharge and water column properties; Environ. Earth. Sci. 69 1033-1043.

Lin Y M, Liu J W, Xiang P, Lin P, Ye G F and Sternberg L S L 2006 Tannin dynamics of propagules and leaves of Kandelia candel and Bruguiera gymnorrhiza in the Jiulong River Estuary, Fujian, China; Biogeochemistry $\mathbf{7 8}$ 343-359.

Liu M, Hou L J, Xu S Y, Ou D N, Yang Y, Yu J and Wang Q 2006 Organic carbon and nitrogen stable isotopes in the intertidal sediments from the Yangtze Estuary, China; Mar. Pollut. Bull. 52 1625-1633.

Lorenzen C J and Jeffrey S W 1980 Determination of chlorophyll in seawater; UNESCO Technical Papers in Marine Science 35 1-20.

Lowry O H, Rosebrough N J, Fart A L and Randall R J 1951 Protein measurement with Folin phenol reagent; J. Biol. Chem. 193 265-275.

Martin G D, Muraleedharan K R, Vijay J G, Rejomon G, Madhu N V and Shivaprasad A et al. 2010 Formation of anoxia and denitrification in the bottom waters of a tropical estuary, southwest coast of India; Biogeosci. Discuss. 7 1751-1782.

Martin G D, Nisha P A, Balachandran K K, Madhu N V, Nair M and Shaiju P et al. 2011 Eutrophication induced changes in benthic community structure of a flow restricted tropical estuary (Cochin backwaters), India; Environ. Monit. Assess. 176 427-438.

Mayer L M, Macko S A and Cammen L 1988 Provenance, concentrations and nature of sedimentary organic nitrogen in the Gulf of Maine; Mar. Chem. 25 291-304.

Menon N N, Balchand A N and Menon N R 2000 Hydrobiology of the Cochin backwater system - A review; Hydrobiologia 430 149-183.

Meyers P A 1997 Organic geochemical proxies of paleoceanographic, paleolimnologic, and paleoclimatic processes; Org. Geochem. 27 214-250.

Mitchell L, Harvey S M, Gage J D and Fallick A E 1997 Organic carbon dynamics in shelf edge sediments off the Hebrides: A seasonal perspective; Int. Rev. Gesamten. Hydrobiol. 82 425-435. 
Moreno S and Niell F X 2004 Scales of variability in the sediment chlorophyll content of the shallow Palmones River Estuary, Spain; Estuar. Coast. Shelf Sci. 60 49-57.

Muraleedharan Nair M N and Ramachandran K K 2002 Textural and trace metal distribution in sediments of Beypore estuary; Indian J. Mar. Sci. 31 295-304.

Muri G, Wakeham S G, Pease T K and Faganeli J 2004 Evaluation of lipid biomarkers as indicators of changes in organic matter delivery to sediments from Lake Planina, a remote mountain lake in NW Slovenia; Org. Geochem. 35 1083-1093.

Nair S M, Balchand A N and Nambisan P N K 1989 On the determination and distribution hydroxylated aromatic compounds in estuarine waters; Toxicol. Environ. Chem. 23 203-213.

Niffy Benny 2009 Unravelling a benchmark for sulphur akin in the Cochin Estuarine System; Ph.D Thesis, Cochin University of Science and Technology, Cochin, Kerala.

Prasad M B K and Ramanathan A L 2008 Sedimentary nutrient dynamics in a tropical estuarine mangrove ecosystem; Estuar. Coast. Shelf Sci. 80 60-66.

Pusceddu A, Sara G, Armeni M, Fabiano M and Mazzola A 1999 Seasonal and spatial changes in the sediment organic matter of a semi-enclosed marine system (W-Mediterranean Sea); Hydrobiologia 397 59-70.

Pusceddu A, Dell'Anno A, Fabiano M and Danovaro R 2009 Quantity and bioavailability of sediment organic matter as signatures of benthic trophic status; Mar. Ecol. Prog. Ser. 375 41-52.

Pusceddu A, Bianchelli S, Gambi C and Danovaro R 2011 Assessment of benthic trophic status of marine coastal ecosystems: Significance of meiofaunal rare taxa; Estuar. Coast. Shelf Sci. 93 420-430.

Qasim S Z 2003 Indian Estuaries; Allied Publishers, New Delhi, 420p.

Raiswell R, Buckley F, Berner R A and Anderson T F 1987 Degree of pyritization of iron as a palaeoenvironmental indicator of bottom-water oxygenation; J. Sedim. Petrol. 58 812-819.

Ramya K D, Jimly C J, Neil S C, Bright Singh I S and Rosamma Philip 2013 Biogeochemistry of the shelf sediments of south eastern Arabian Sea: Effect on benthic bacterial heterotrophs; Adv. Appl. Sci. Res. 4 315-328.

Ramaswamy V, Gaye B, Shirodkar P, Rao P, Chivas A, Wheeler D and Thwin S 2008 Distribution and sources of organic carbon, nitrogen and their isotopic signatures in sediments from the Ayeyarwady (Irrawaddy) continental shelf, northern Andaman Sea; Mar. Chem. 111 137-150.

Ranjan R K, Routh J, Ramanathan A L and Klump J V 2011 Elemental and stable isotope records of organic matter input and its fate in the Pichavaram mangroveestuarine sediments (Tamil Nadu, India); Mar. Chem. $126163-172$.

Rasheed K 1997 Studies on dredging impact assessment (DIA) at Cochin, a tropical estuarine harbor; Ph.D Thesis, Cochin University of Science and Technology, Cochin, Kerala.

Renjith K R, Chandramohanakumar N and Joseph M M 2011 Fractionation and bioavailability of phosphorus in a tropical estuary, southwest India; Environ. Monit. Assess. $174299-312$.

Renjith K R, Manju Mary Joseph, Prosenjit Ghosh K, Habeeb Rahman, Ratheesh Kumar C S and Chandramohanakumar N 2012 Biogeochemical facsimile of the organic matter quality and trophic status of a micro-tidal tropical estuary; Environ. Earth. Sci., doi: 10.1007/s12665-012-2159-0.

Rice D L 1982 The detritus nitrogen problem: New observations and perspectives from organic geochemistry; Mar. Ecol. Prog. Ser. 9 153-162.

Rossi F, Como S, Cort S and Lardicci C 2001 Seasonal variation of a deposit-feeders assemblage and sedimentary organic matter in a brackish basin mudflat (Western Mediterranean, Italy); Estuar. Coast. Shelf Sci. $\mathbf{5 3}$ 181-191.

Rossi F and Lardicci C 2002 Role of the nutritive value of sediment in regulating population dynamics of the deposit-feeding polychaete Streblospio shrubsolii; Mar. Biol. 140 1129-1138.

Smith V H 2003 Eutrophication of freshwater and coastal marine ecosystems. A global problem; Environ. Sci. Poll. Res. 10 126-139.

Srinivas K 2000 Seasonal and interannual variability of sea level and associated surface meteorological parameters at Cochin; PhD Thesis, Cochin University of Science and Technology, Cochin, Kerala.

Srinivas K, Revichandran C, Maheswaran P A, Mohammed Ashraf T T and Nuncio M 2003 Propagation of tides in the Cochin estuarine system, southwest coast of India; Indian J. Mar. Sci. 32 14-24.

Szymczak-Zyła M and Kowalewska G 2007 Chloropigments$a$ in the Gulf of Gdańsk (Baltic Sea) as markers of the state of this environment; Mar. Pollut. Bull. 55 $10-12$.

Tan F C, Cai D L and Edmon J M 1991 Carbon isotope geochemistry of the Changjiang estuary; Estuar. Coast. Shelf Sci. 32 395-404.

Thomson K T 2002 Economic and social issues of biodiversity loss in Cochin backwaters; Technical report, Cochin University of Science and Technology, Cochin, India, pp. 51-82.

Thornton S F and Mc-Manus J 1994 Application of organic carbon and nitrogen stable isotope and $\mathrm{C} / \mathrm{N}$ ratios as source indicators of organic matter provenance in estuarine systems - Evidence from the Tay estuary, Scotland; Estuar. Coast. Shelf Sci. 38 219-233.

Thottathil S D, Balachandran K K, Gupta G V M, Madhu N V and Nair S 2008 Influence of allochthonous input on autotrophic-heterotrophic switch-over in shallow waters of a tropical estuary (Cochin Estuary), India; Estuar. Coast. Shelf Sci. 78 551-562.

Vasudevan P N 2000 Biogeo-oragnics in the sedimentary environment of Cochin estuary; Ph.D Thesis, Cochin University of Science and Technology, Kerala, India.

Venturini N, Pita A, Brugnoli E, García-Rodriguez F, Burone L, Kandratavicius N, Hutton M and Muniz P M 2012 Benthic trophic status of sediments in a metropolitan area (Rio de la Plata estuary): Linkages with natural and human pressures; Estuar. Coast. Shelf Sci. 112 $139-152$.

Wen L S, Warnken K W and Santschi P H 2008 The role of organic carbon, iron, and aluminium oxyhydroxides as trace metl carriers: Comparison between the Trinity River and the Trinity River Estuary (Galveston Bay, Texas); Mar. Chem. 112 20-37.

Yamamuro M 2000 Chemical tracers of sediment organic matter origins in two coastal lagoons; J. Marine Syst. 26 $127-134$. 